\title{
Root tuber extract of Polygooum cillinerve (Nakai) Ohwi exerts antimicrobial and immunomodulatory activities
}

\author{
Lanxiu Cao*, Juan Lv, Xian Zhao, Jiang Wang, Li Ma \\ Department of Chinese materia medica, Shanxi University of Traditional Chinese Medicine, Xianyang City, Shan Xi Province, \\ China, 712046
}

*For correspondence: Email: LanxiuCaozxc@163.com; Tel: +86-29-38185353

\begin{abstract}
Purpose: To investigate the antibacterial and immunomodulatory activities of the root tuber extract of Polygonum ciliinerve (Nakai) ohwi, a traditional Chinese medicine.

Methods: Minimum inhibitory concentrations (MICs) of root tuber extract of Polygonum ciliinerve (Nakai) ohwi ( $r P C)$ and the synergistic effects between rPC and antibiotics were evaluated by broth dilution. In vitro adhesion and invasion assays were used to determine the effect of rPC on bacterial adhesion and invasion. Furthermore, the immunomodulatory effects of rPC were assessed by western blot.

Results: $r P C$ treatment inhibited the growth of Staphylococcus aureus $(M I C=12 \mathrm{mg} / \mathrm{ml}$ ) and Escherichia coli (MIC $=64 \mathrm{mg} / \mathrm{mL}$ ). $r$ PC also showed synergistic effects with penicillin (fractional inhibitory concentration, $F I C=0.45)$, vancomycin $(F I C=0.333)$, moxifloxacin $(F I C=0.25)$, and levofloxacin $(F I C=0.356)$. The adhesion and invasion of bacteria were also suppressed by rPC treatment. Moreover, rPC exhibited an immunomodulatory effect during bacterial infection.

Conclusion: rPC shows antibacterial and immunomodulatory activites when assessed by multiple methods, and therefore is a potential therapeutic alternative agent for the treatment of bacterial infections.
\end{abstract}

Keywords: Polygonum ciliinerve root tuber, Synergistic effect, Immunomodulatory, Antibacterial

\begin{abstract}
This is an Open Access article that uses a funding model which does not charge readers or their institutions for access and distributed under the terms of the Creative Commons Attribution License (http://creativecommons.org/licenses/by/4.0) and the Budapest Open Access Initiative (http://www.budapestopenaccessinitiative.org/read), which permit unrestricted use, distribution, and reproduction in any medium, provided the original work is properly credited.

Tropical Journal of Pharmaceutical Research is indexed by Science Citation Index (SciSearch), Scopus, International Pharmaceutical Abstract, Chemical Abstracts, Embase, Index Copernicus, EBSCO, African Index Medicus, JournalSeek, Journal Citation Reports/Science Edition, Directory of Open Access Journals (DOAJ), African Journal Online, Bioline International, Open-J-Gate and Pharmacy Abstracts
\end{abstract}

\section{INTRODUCTION}

The widespread clinical use of antibiotics combined with a shortage of new antimicrobials, has resulted to bacterial pathogens with drug resistance [1]. Consequently, infectious diseases caused by bacterial pathogens have resulted in increased morbidity and mortality worldwide and are a serious threat to public health [2].
The pharmaceutical industry is devoted to developing new antibiotics to overcome antimicrobial resistance. Screening bioactive compounds from microbes and improving the chemical structures of these bioactive compounds are the most common strategy. In addition, natural products are an important treasury for new antibacterial drugs and have historically provided people with a source of organic molecules to treat infections [3]. Modern 
pharmacology has shown that natural products have antimicrobial activity and show a synergistic effect with antibiotics $[3,4]$.

Polygonum ciliinerve (Nakai) ohwi, belonging to Polygonum of Polygonaceae, is popularly used as an antimicrobial in China. As an herbal medicine, rPC is the effectual component of Polygonum ciliinerve (Nakai) ohwi used for disease treatment by recordation. Modern pharmacological analysis showed polysaccharides and anthraquinones were regarded as the active ingredients of rPC [5-7]. Although early studies showed that rPC possesses anti-oxidant and antifungal activities, the antimicrobial activities of $\mathrm{rPC}$ remain to be explored $[6,8,9]$.

This study elucidated the antibacterial activities of rPC using several assays, including traditional bacteriostasis assessments, drug combination assays, bacterial adhesion and invasion assays, and assessments to determine immunomodulatory effects. Based on these results, rPC may be expected to be a therapeutic alternative for infectious diseases and may also provide a lead for the development of herbal antimicrobial medicines.

\section{EXPERIMENTAL}

\section{rPC preparation}

rPC was purchased from $\mathrm{Hu}$ Qing $\mathrm{Yu}$ Chinese Pharmacy. Pulverized rPC was extracted by twice refluxing in $30 \%$ ethanol for $3 \mathrm{~h}$ at $100{ }^{\circ} \mathrm{C}$. The extract was passed through a $50-\mu \mathrm{m}$ filter and isolated as a lyophilized powder.

\section{Bacterial strains, cells, and chemicals}

S. aureus ATCC6538 and E. coli ATCC25922 were incubated in Luria Broth (LB) medium at 37 ${ }^{\circ} \mathrm{C}$. Fetal human colon (FHC) cells were purchased from the Chinese Academy of Sciences. Gentamicin, penicillin, vancomycin, moxifloxacin, and levofloxacin were purchased from Sigma-Aldrich. A cell counting kit-8 (CCK-8) was acquired from Dojindo.

\section{Evaluation of MIC and time-kill assay}

MICs were measured by broth dilution in accordance with the guidelines of the Clinical and Laboratory Standards Institute (CLSI). Serial dilutions of $\mathrm{rPC} /$ antibiotics were prepared in 96well plates, and bacteria $\left(10^{5} \mathrm{CFU} / \mathrm{mL}\right)$ were inoculated into each well. The 96-well plates were incubated for $24 \mathrm{~h}$ at $37{ }^{\circ} \mathrm{C}$, and absorbance at a wavelength of $600 \mathrm{~nm}$, was measured. The minimum concentrations of rPC/antibiotics that inhibited the growth of bacteria were the MICs. Absorbance was measured with a SpectraMax M3 multi-mode microplate reader (Molecular Devices) to monitor the number of bacteria.

$S$. aureus and E. coli were cultured in LB medium with different concentrations of $\mathrm{rPC}(0$, $0.125,0.25,1 \times \mathrm{MIC})$ at $37{ }^{\circ} \mathrm{C}$ for $24 \mathrm{~h}$. The samples were removed, diluted $(1: 10)$, and the absorbance measured at $600 \mathrm{~nm}$ wavelength hourly. Standard growth curves constructed by plotting absorbance against colony forming units per milliliter (CFU/mL) in order to calculate $\mathrm{CFU} / \mathrm{mL}$ of $S$. aureus and E. coli.

\section{Synergism test}

Different concentrations of $\mathrm{rPC}$ and antibiotics were put together in 96-well plates (each concentration was lower than the determined $\mathrm{MIC})$. S. aureus $\left(10^{5} \mathrm{CFU} / \mathrm{mL}\right)$ was inoculated into each well. After incubation for $24 \mathrm{~h}$ at $37^{\circ} \mathrm{C}$, the $\mathrm{OD}_{600}$ of the 96 -well plates was measured. The combinations that yielded minimal concentrations of rPC and antibiotics that inhibited the growth of bacteria indicated the combined MIC.

For component $A$, the FIC of $A$ was calculated as the combined MIC of $A$ divided by the MIC of $A$ alone. The FIC index was the sum of the FICs for each combined component. The interactions are considered antagonistic if FIC index $>2$, indifference if $1<\mathrm{FIC}$ index $<2$, additive if FIC index $=1$, and synergistic if FIC index $<1$.

\section{Adhesion and invasion assay}

FHC cells $\left(10^{5}\right.$ cells per well) were seeded into 24-well plates 1 day before the assay, and the medium was changed to serum-free medium $1 \mathrm{~h}$ before infection. S. aureus $\left(10^{6} \mathrm{CFU}\right)$ was added to each well in addition to different concentrations of $\mathrm{rPC}(0,0.25,0.5,1 \times \mathrm{MIC})$, and the plates were centrifuged $(2000 \mathrm{rpm}, 10$ $\min$ ) to allow infection. For the adhesion assay, FHC cells were lysed $(0.1 \%$ Triton) after washing, and the $\mathrm{OD}_{600}$ was measured. For the invasion assay, the 24-well plates were incubated for $40 \mathrm{~min}$ and washed three times with PBS. Cells were incubated with gentamicincontaining medium $(25 \mu \mathrm{g} / \mathrm{mL})$ for another $1 \mathrm{~h}$ and lysed to determine CFUs.

\section{Western blot}

FHC cells $\left(10^{6}\right.$ cells per well) were seeded into 6 well plates and treated with $S$. aureus $\left(10^{7} \mathrm{CFU}\right)$ 
and $\mathrm{rPC}(0,0.25,0.5,1 \times \mathrm{MIC})$ for $24 \mathrm{~h}$. Cells were lysed in RIPA lysis and extraction buffer (Thermo Fisher Scientific) with protease inhibitors (Sigma-Aldrich). A BCA Protein Assay Kit (Thermo Fisher Scientific) was used to determine protein concentrations. Ten-microliter protein samples were electrophoresed with SDS polyacrylamide gels and transferred to PVDF membranes (Millipore). The membranes were blocked by TBST (tris-buffered saline with Tween 20) containing $5 \%$ skim milk for $3 \mathrm{~h}$ and washed three times with TBST. The primary antibodies against GAPDH (Abcam), p38 (Abcam), phosphorylated-p38 (Abcam), ERK (Abcam), phosphorylated-ERK (Abcam), IKBa (Abcam) and phosphorylated-IKBa (Abcam) were incubated with the membranes overnight at $4^{\circ} \mathrm{C}$. After washing with TBST, horseradish peroxidase (HRP)-conjugated secondary antibodies (Abcam) were incubated with the membranes at room temperature for $1 \mathrm{~h}$. The chemiluminescence induced by SuperSignal West Dura Extended Duration Substrate (Thermo Fisher Scientific) was detected with ImageQuant LAS 4000mini (GE Healthcare Life Sciences).

\section{Statistical analysis}

Data were collected from three independent experiments and are expressed as mean \pm standard error of mean (SEM). The statistical significance of differences between two groups was evaluated with the Mann-Whitney test. SPSS and Prism software was used to perform the statistical analysis, with $p<0.05$ indicating significance.

\section{RESULTS}

\section{Antimicrobial activity of rPC}

The antibacterial activities of rPC against $S$. aureus and $E$. coli were determined through by broth dilution. The MICs of rPC against $S$. aureus and $E$. coli were 12 and $64 \mathrm{mg} / \mathrm{ml}$, respectively (Figure 1A). These results suggest that rPC exhibits antimicrobial activities against both gram-negative and gram-positive bacteria.

Based on the MIC of rPC, time-kill curves of $S$. aureus and $E$. coli were also obtained (Figure 1B). After exposure to $\mathrm{rPC}(0,0.125,0.25,0.5$, $1.0 \times \mathrm{MIC})$, the viable count was tested every hour through measurement of $\mathrm{OD}_{600}$. When compared with the control, rPC successfully restricted viable cell count. Moreover, rPC showed effective and prolonged bactericidal ability at the MIC concentration within $24 \mathrm{~h}$. Taken together, rPC has broad and strong antibacterial activities.

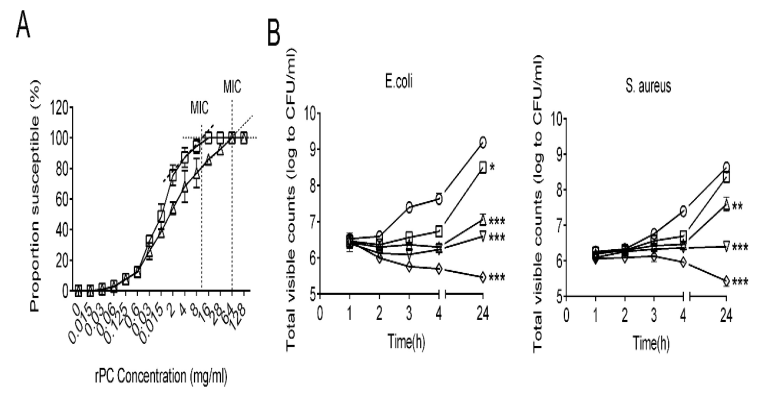

Figure 1: Antimicrobial activity of rPC.(A) Inhibition of the growth of $S$. aureus and $E$. coli by various concentrations of rPC; $\square:$ E.coli, $\Delta: S$.aureus. (B) Timekill curves for $S$. aureus and $E$. coli treated with $\mathrm{rPC}(0$, $0.125,0.25,0.5,1 \times \mathrm{MIC}) ;{ }^{* *} p<0.01,{ }^{* * *} p<0.001$, compared with control group 2 . Control; $\square: 018 \times$ MIC rPC

\section{Synergistic effect of rPC and antibiotics}

To further evaluate potential applications of rPC, the synergistic activity of rPC and antibiotics was tested. FIC index was used as indicators of the synergistic effect against $S$. aureus. The FIC index of rPC and antibiotics ranged from 0.2 to 0.5 , indicative of synergistic effects (FIC $\leq 0.5$ ) (Table 1). The combined use of rPC and Moxifloxacin showed the strongest synergistic effect $(F I C=0.25)$. The results indicate that rPC could be used in clinical treatment to improve the utilization efficiency of antibiotics and decrease the overuse of antibiotics.

Table 1: Effect of combined antibacterial agents on the growth of $S$. aureus in LB medium at $37^{\circ} \mathrm{C}$. FIC index $<$ 0.5 considered as synergistic

\begin{tabular}{lcccccc}
\hline Component & \multicolumn{2}{c}{ Single MIC } & \multicolumn{2}{c}{ Combined MIC } & \multirow{2}{*}{ FIC } \\
$A$ & $B$ & $A(m g / m L)$ & $B(\mu g / m L)$ & $A(m g / m L)$ & $B(\mu g / m L)$ & \\
\hline rPC & Penicillin & 12 & 0.12 & 3 & 0.024 & 0.45 \\
rPC & Vancomycin & 12 & 8 & 1 & 2 & 0.333 \\
rPC & Moxifloxacin & 12 & 60 & 1 & 10 & 0.25 \\
rPC & Levofloxacin & 12 & 0.53 & 2 & 0.1 & 0.356 \\
\hline
\end{tabular}


A

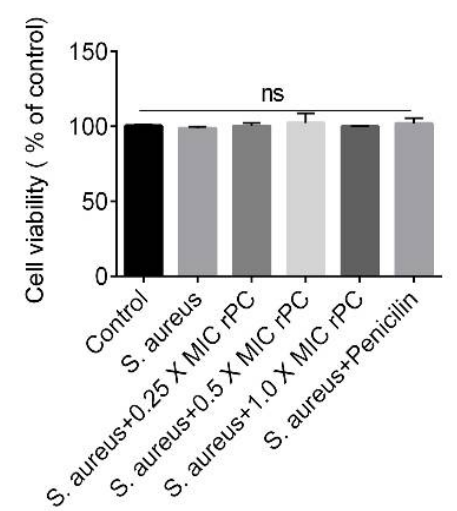

B

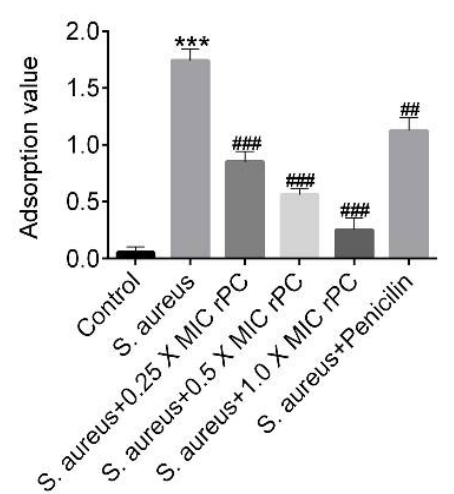

C

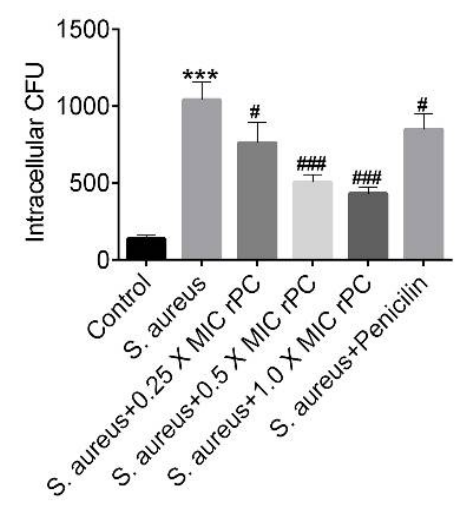

Figure 2: Effect of $\mathrm{rPC}$ on $S$. aureus infection of enterocytes in vitro. (A) FHC cells were exposed to $S$. aureus and $\mathrm{rPC}(0,0.25,0.5,1 \times \mathrm{MIC})$ for $2 \mathrm{~h}$. Cell viability was determined with a CCK-8 assay. (B and C) The effects of $\mathrm{rPC}(0,0.25,0.5,1 \times \mathrm{MIC})$ on $S$. aureus adhesion to $(\mathrm{B})$ and invasion of $(\mathrm{C}) \mathrm{FHC}$ cells during bacterial

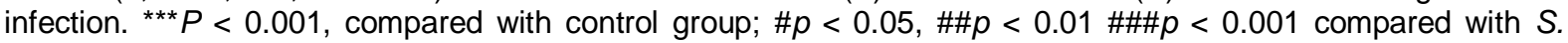
aureus infection group

\section{rPC inhibited $S$. aureus infection of enterocytes in vitro}

To identify whether the antimicrobial activity of rPC correlated with the inhibition of bacterial infection, the adhesion and invasion of enterocytes by $S$. aureus was quantified with conventional infection assays. First, the cytotoxic effect of $\mathrm{rPC}(0,0.25,0.5,1 \times \mathrm{MIC})$ and $S$. aureus on FHC cells was determined, and no obvious cytotoxic effects was found (Figure 2A). In the assay, Penicillin was used as a positive control. rPC reduced $S$. aureus adhesion and invasion to $\mathrm{FHC}$ cells in a dose-dependent manner (Figures $2 \mathrm{~B}$ and $\mathrm{C}$ ). Furthermore, rPC had a stronger effect on inhibition of bacterial adhesion and invasion than penicillin which only inhibits bacterial growth, indicating that $\mathrm{rPC}$ has a direct effect on bacterial adhesion and invasion (Figure $2 \mathrm{~B}$ and $\mathrm{C}$ ).

\section{rPC ameliorated the inflammatory response of infected cells}

$S$. aureus may induce cellular immune responses after invasion by activating the MAPK/ERK and NF-KB signaling pathways[10,11]. Therefore, FHC cells were infected with $S$. aureus, and the expression of typical proteins was analyzed after rPC treatment $(0,0.25,0.5,1 \times \mathrm{MIC})$. Phosphorylation of p38 (MAPK14), ERK, and IKBa were observed after $S$. aureus infection, suggesting that the MAPK/ERK and NF- $\square \mathrm{B}$ pathways were activated (Figure 3). However, rPC treatment significantly decreased the activation of $\mathrm{p} 38$, ERK, and IKBa, indicating a reduced inflammatory response in enterocytes (Figure 3). These results demonstrate that rPC could act to maintain cellular immune homeostasis during bacterial infection.

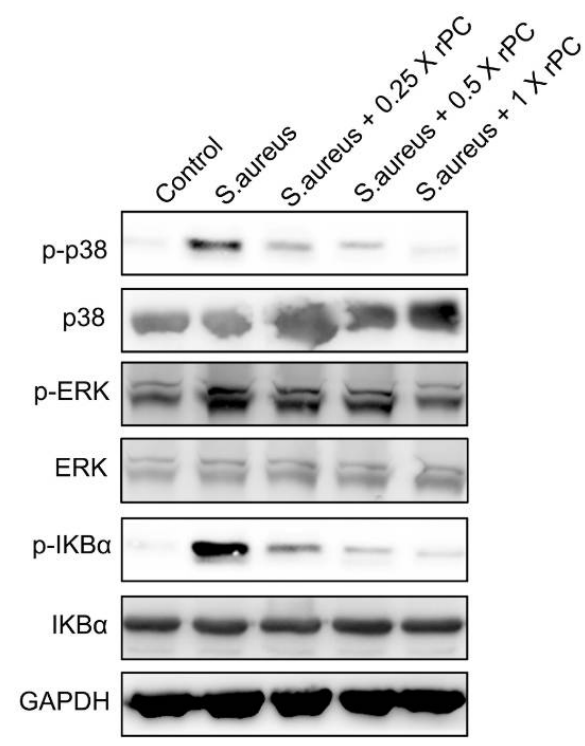

Figure 3: rPC ameliorated the inflammatory response of infected cells. The expression of phosphorylatedp38, p38, phosphorylated-ERK, ERK, phosphorylated$\mathrm{IKBa}$, and IKBa in $\mathrm{FHC}$ cells with different treatment

\section{DISCUSSION}

In order to decrease the morbidity and mortality of infectious diseases, it is important to discover new drugs with effective antibacterial activities. Traditional herbal medicines were considered to possess effective antimicrobial activities and hard to acquire drug resistance [12]. Therefore, rPC, an anti-infective drug in traditional Chinese medicine, has the potential to become a novel therapy for bacterial infections. In this study, the antibacterial activity of $\mathrm{rPC}$ and its synergistic 
effect with antibiotics were evaluated. In addition, other antibacterial activities of $\mathrm{rPC}$ were also assessed, particularly inhibition of bacterial adhesion and invasion, which in-turn modulates the immune responses of infected cells.

In the present study, rPC showed antimicrobial activity against $S$. aureus and $E$. coli (MIC = 12and $64 \mathrm{mg} / \mathrm{mL}$, respectively). Consistent with the records of Bencao Tujing (published in 1061, China), rPC served as an anti-infection agent. Emodin and physcion, the effective of rPC, have strong bactericidal effects $[5,13,14]$. Therefore, rPC possessed natural antibacterial activity. Moreover, the time-kill assays illustrated that rPC can inhibit bacteria growth at concentrations $\geq 0.5 \times$ MIC.

Synergistic effects were observed between rPC and antibiotics. The combined concentrations of rPC and antibiotics inhibiting bacterial growth were much lower than single use. Therefore, rPC probably can be used as an adjuvant to effectively prevent drug resistance to antibiotics. However, the experimental conditions in this study were limited (bacteria was incubated in culture medium within a $24 \mathrm{~h}$ period); also, the pathophysiological condition of human body is more complicated and hence further studies need to be done.

Pathogenic bacteria, such as $S$. aureus and $E$. coli, have sophisticated adhesion systems, like flagella and fimbriae, conducting efficient cellular adhesion and invasion [15,16]. In addition, microorganisms can utilize extracellular matrix such as fibronectin, to promote adhesion and invasion [17]. The findings of this study suggest that rPC suppresses bacterial adhesion and invasion.

NF-kB and p38/MAPK signaling pathways link extracellular stimuli with inflammatory responses $[18,19]$. In the current study, rPC treatment reduced the activation of $\mathrm{p} 38, \mathrm{ERK}$ and $\mathrm{IKBa}$ compared with the $S$. aureus group, which indicated that rPC can attenuate inflammation of infected cells. Therefore, the immunomodulatory effects of rPC should be further explored.

\section{CONCLUSION}

This study demonstrates that rPC possesses strong antibacterial activities and has a synergistic effect with antibiotics. Moreover, the results suggest that $\mathrm{PPC}$ inhibits bacterial adhesion, suppresses bacterial invasion, and plays an immunomodulatory role in host cells. Based on these results, rPC is a promising medicinal agent for the treatment of infectious diseases, and may potentially help to tackle antibiotic resistance.

\section{DECLARATIONS}

\section{Acknowledgement}

This work was funded as part of projects titled 'A study on the effects of Polygonum cillinerve on Staphylococcus aureus and TLR/NOD pathway on the basis of mutant selection window' (grant no. 2017JM8021) and 'A Study on the effects of total flavonoid in ligustrum lucidum ait on lipidmetabolite and the related mechanism' (grant no. 2010Jk476), respectively.

\section{Conflict of interest}

The authors declare that there is no conflict of interest associated with this work.

\section{Contribution of authors}

We declare that this work was done by the authors named in this article and all liabilities pertaining to claims relating to the content of this article will be borne by the authors. Lanxiu Cao and Juan Lv designed all the experiments and revised the paper. Xian Zhao and Jiang Wang performed the experiments while Li Ma wrote the paper.

\section{REFERENCES}

1. Fernandez L, Hancock RE. Adaptive and mutational resistance: role of porins and efflux pumps in drug resistance. Clin Microbiol Rev 2012; 25(4): 661-681.

2. Armstrong GL, Conn LA, Pinner RW. Trends in infectious disease mortality in the United States during the 20th century. Jama 1999; 281(1): 61-66.

3. Davies J. How to discover new antibiotics: harvesting the parvome. Curr Opin Chem Biol 2011; 15(1): 5-10.

4. Gibbons S. Anti-staphylococcal plant natural products. Nat Prod Rep 2004; 21(2): 263-277.

5. Chen ZF, Gang AS. Content of Active Component in Wild Medicinal Plant Polygonum ciliinerve Determined by HPLC and Their Relationship with Tuber Size. J Hebei Agric Sci 2011;1: 137-142.

6. Cui JJ, Yuan JF, Zhang ZQ. Extraction and Biological Activity of Crude Polysaccharide from Polygonum ciliinerve. Nat Prod Res Dev 2007; 19(6): 960-964.

7. Wu $Y$, Wang $X$, Liu $P$, Niu $Q, W u$. Quantitative Determination of Anthraquinones and Resveratrol in Polygonum Cillinerve (Nakai) Ohwi by HPLC-PAD. J AOAC Int 2017; 100(1): 25-29.

8. Cui JJ, Yuan JF, Zhang ZQ. Anti-oxidation activity of the crude polysaccharides isolated from Polygonum 
cillinerve (Nakai) Ohwi in immunosuppressed mice. J Ethnopharmacol 2010; 132(2): 512-517.

9. Qi HY, Zhang CF, Zhang M, Wang ZT. Studies on constituents and antifungal activity of Polygonum cillinerve. Chin Pharma J 2005; 40(11): 819-822.

10. Arbibe L, Mira JP, Teusch N, Kline L, Guha M, Mackman N, Godowski PJ, Ulevitch RJ, Knaus UG. Toll-like receptor 2/[ndash]/mediated NF-|[kappa]/B activation requires a Rac1-dependent pathway. Nature Immunol 2000; 1(6): 533-540.

11. Neumann $Y$, Bruns SA, Rohde M, Prajsnar TK, Foster SJ, Schmitz I. Intracellular Staphylococcus aureus eludes selective autophagy by activating a host cell kinase. Autophagy 2016; 12(11): 2069-2084.

12. Cai Y, Zhang Q, Fu Y, Li L, Zhao N, Lu A, Liu Q, Jiang $M$. Effectiveness of Chinese Herbal Medicine Combined with Antibiotics for Extensively Drug-Resistant Enterobacteria and Nonfermentative Bacteria Infection: Real-Life Experience in a Retrospective Cohort. Biomed Res Int 2017; 11: e2897045

13. Liu M, Peng W, Qin R, Yan Z, Cen Y, Zheng X, Pan X, Jiang $W, L i B, L i X$ et al. The direct anti-MRSA effect of emodin via damaging cell membrane. Appl Microbiol Biotechnol 2015; 99(18): 7699-7709.

14. Basu S, Ghosh A, Hazra B. Evaluation of the antibacterial activity of Ventilago madraspatana Gaertn., Rubia cordifolia Linn. and Lantana camara Linn.: isolation of emodin and physcion as active antibacterial agents. Phytother Res 2005; 19(10): 888-894.

15. Donnenberg MS. Pathogenic strategies of enteric bacteria. Nat 2000; 406(6797): 768-774.

16. Pizarro-Cerda J, Cossart P. Bacterial adhesion and entry into host cells. Cell 2006; 124(4): 715-727.

17. Konkel ME, Larson CL, Flanagan RC. Campylobacter jejuni FlpA binds fibronectin and is required for maximal host cell adherence. J Bacteriol 2010; 192(1): 68-76.

18. Bode JG, Ehlting C, Haussinger D. The macrophage response towards LPS and its control through the p38(MAPK)-STAT3 axis. Cell Signal 2012; 24(6): 11851194.

19. Bhatt D, Ghosh S. Regulation of the NF-kappaBMediated Transcription of Inflammatory Genes. Front Immunol 2014; 5: 71-78. 